\title{
Leaders in collective migration: are front cells really endowed with a particular set of skills? [version 1; peer review: 2
}

\section{approved]}

\author{
Eric Theveneau (i)1, Claudia Linker² \\ ${ }^{1}$ Centre de Biologie du Développement (CBD), Centre de Biologie Intégrative (CBI), Université de Toulouse, CNRS, UPS, France \\ ${ }^{2}$ Randall Division of Cell \& Molecular Biophysics, King's College London, London, UK
}

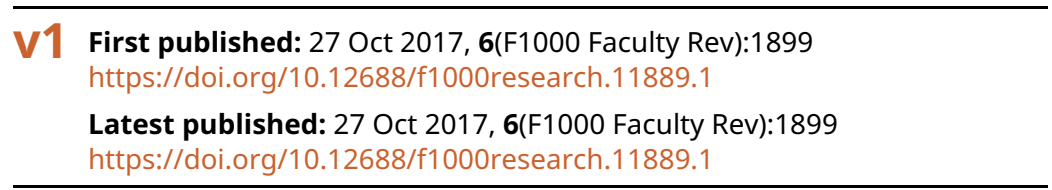

\section{Abstract}

Collective cell migration is the coordinated movement emerging from the interaction of at least two cells. In multicellular organisms, collective cell migration is ubiquitous. During development, embryonic cells often travel in numbers, whereas in adults, epithelial cells close wounds collectively. There is often a division of labour and two categories of cells have been proposed: leaders and followers. These two terms imply that followers are subordinated to leaders whose proposed broad range of actions significantly biases the direction of the group of cells towards a specific target. These two terms are also tied to topology. Leaders are at the front while followers are located behind them. Here, we review recent work on some of the main experimental models for collective cell migration, concluding that leader-follower terminology may not be the most appropriate. It appears that not all collectively migrating groups are driven by cells located at the front. Moreover, the qualities that define leaders (pathfinding, traction forces and matrix remodelling) are not specific to front cells. These observations indicate that the terms leaders and followers are not suited to every case. We think that it would be more accurate to dissociate the function of a cell from its position in the group. The position of cells can be precisely defined with respect to the direction of movement by purely topological terms such as "front" or "rear" cells. In addition, we propose the more ample and strictly functional definition of "steering cells" which are able to determine the directionality of movement for the entire group. In this context, a leader cell represents only a specific case in which a steering cell is positioned at the front of the group.

\section{Keywords}

collective cell migration, migratory cells, cell topology

\section{Open Peer Review}

Approval Status

1 2

version 1

27 Oct 2017

Faculty Reviews are review articles written by the prestigious Members of Faculty Opinions. The articles are commissioned and peer reviewed before publication to ensure that the final, published version is comprehensive and accessible. The reviewers who approved the final version are listed with their names and affiliations.

1. Benoit Ladoux, Universite Paris Diderot,

Paris, France

\section{Denise Montell, University of California, \\ Santa Barbara, Santa Barbara, USA}

Any comments on the article can be found at the end of the article. 
Corresponding authors: Eric Theveneau (eric.theveneau@univ-tlse3.fr), Claudia Linker (claudia.linker@kcl.ac.uk)

Author roles: Theveneau E: Conceptualization, Supervision, Writing - Original Draft Preparation, Writing - Review \& Editing; Linker C: Conceptualization, Writing - Original Draft Preparation, Writing - Review \& Editing

Competing interests: The authors declare that they have no competing interests.

Grant information: Work in the ET lab is supported by the Centre National de la Recherche Scientifique (CNRS) and grants from the Fondation pour la Recherche Médicale (FRM AJE201224), the Midi-Pyrénées regional council (13053025) and Fondation Toulouse Cancer Santé (Math/Bio Interface grant). Work in the CL lab is supported by the Medical Research Council and the Wellcome Trust. The funders had no role in study design, data collection and analysis, decision to publish, or preparation of the manuscript.

Copyright: $\odot 2017$ Theveneau E and Linker C. This is an open access article distributed under the terms of the Creative Commons Attribution License, which permits unrestricted use, distribution, and reproduction in any medium, provided the original work is properly cited.

How to cite this article: Theveneau $E$ and Linker $C$. Leaders in collective migration: are front cells really endowed with a particular set of skills? [version 1; peer review: 2 approved] F1000Research 2017, 6(F1000 Faculty Rev):1899

https://doi.org/10.12688/f1000research.11889.1

First published: 27 Oct 2017, 6(F1000 Faculty Rev):1899 https://doi.org/10.12688/f1000research.11889.1 


\section{Introduction}

Collective cell migration is the coordinated motion of a group of cells that emerges from their chemical, physical and/or mechanical interaction ${ }^{1-3}$. Collective cell migration is a prevalent feature during development. Morphogenesis is achieved by orchestrating cell specification and patterning and coordinating movement of cells over time. The main movements of cells are intercalation and single or collective cell migration. Collectively migrating groups can be formed of epithelial or mesenchymal cells originating from one cell population or composed of a mixture of cell types. Different modes of cooperation have been described, from the tightly interconnected epithelial sheets or strands to the loose streams of individual cells communicating via transient contacts and secreted signals.

Often the role of the different cells in the collectively migrating group is described through division of labour in two categories: leader or follower cells ${ }^{4-6}$. Leader cells are located at the front of the group and allegedly control directionality of movement. Khalil and Friedl originally proposed that leaders would act by "exploring the environment, finding the path, generating traction force and proteolytically remodelling the extracellular matrix" . Accordingly, follower cells trail leaders and have been proposed to be defined by their inability to generate their own tracks ${ }^{7}$. Since this original framing of the concept, experimental data from epithelial and mesenchymal models of collective migration, which we comment on hereafter, indicate that (i) directionality of the group is not systematically set by cells located at the front, (ii) generation of traction forces and protrusive and proteolytic activities are not specific to front cells, and (iii) protrusive activity and the ability to guide a group of cells are uncoupled.

It was recently recognized that, in conjunction with chemical signals, the physical interaction between cells plays a fundamental role during collective migration ${ }^{2}$. Therefore, unveiling the mechanisms regulating this process will require an interdisciplinary approach comprising biology, physics and mathematics. Multiple agent-based or continuous mathematical models of collective cell movement have been proposed and reviewed elsewhere ${ }^{8-17}$. These models incorporate strategies previously used in a variety of systems from swarming of bacteria, flocking of birds or schooling fish to foam dynamics. It turns out that modulation of cell motility and cell mechanical interactions are the key parameters sufficient to recapitulate the main cell behaviours observed in vivo and in vitro. Interestingly, in the context of mechanically interacting cells, a small fraction of cells responding to an external signal is sufficient to significantly bias the direction of movement ${ }^{10}$. Importantly, though, these cells do not need to be at the front of the population or to be organized into a specific subgroup. They can act while being evenly scattered across the cell population. Additionally, models of epithelial cell monolayers in which no differentiation into leader cells is implemented ${ }^{18}$ still recapitulate experimental data on wound closure ${ }^{19}$. Furthermore, models of cooperation among mesenchymal cells show that local cell interactions and confinement, in the absence of leader-follower identities and external gradients, are sufficient to achieve directional movement ${ }^{9}$. Overall, in silico studies suggest that (i) directional collective migration can occur in the absence of a specialized subset of cells and (ii) when specialized cells are present, these do not need to be localized at the front of the group to drive collective migration.

Altogether, experimental and in silico data indicate that the original do-it-all leader and passive follower nomenclature is not suitable. In addition, we think that the leader-follower terminology is biased as it combines function and position when these may be uncoupled and leads to the expectation that front cells have a prominent guidance role. Therefore, we propose to introduce a purely functional "steering cell" term, of which a looser leader cell definition might represent a specific subtype of specialized front cell. The steering cell term should, in turn, be used together with purely topological terms such as "front cell" or "rear cell".

\section{Epithelial models of collective cell migration}

There are several models of collective migration of epithelial cells. Some of the most common include mammalian epithelial monolayers in culture ${ }^{20}$, sprouting blood vessels ${ }^{21}$, tracheal cells $^{22}$ and germ-band extension ${ }^{23}$ of the Drosophila embryo as well as border cells of the drosophila egg chamber ${ }^{24}$.

Epithelial monolayers are extremely large systems formed by hundreds of cells. Experimental setups start with a confluent monolayer in which space is generated by wounding, scratching or lifting barriers that separate two populations. A limited number of leader cells emerge at the free edge. It has been shown that Notch lateral inhibition, mechanical cues and topology $y^{25,26}$ are pivotal for leader cell selection. Indeed, once leaders emerge, they take on a specific morphology characterized by a pseudomesenchymal phenotype with a large lamellipodia at the free edge $e^{20,25,27,28}$. Leader cells are linked to the rest of the group by actomyosin cables ${ }^{29}$. Such cables mechanically couple leaders with their immediate neighbours and play a role in preventing adjacent cells from displaying protrusive activity. Follower cells, located behind leaders, establish their directionality through communication with leaders. This relies on signalling molecules and on the local balance of forces. In extreme cases, leader cells can pull a so-called finger, formed of multiple follower cells, from the epithelial monolayer to invade the free space ${ }^{30,31}$. The whole structure has actin cables running along the side membranes from the leader at the tip through the several rows of followers behind. Thus, the finger behaves as a super cell with a distribution of actin polymerization and actomyosin contraction spanning several cells along the finger ${ }^{30}$. In this situation, motility is not restricted to front cells, even if leaders can exert more force ${ }^{28,29,32,33}$. The number of leader cells has been shown to be regulated by Notch lateral inhibition ${ }^{25,26}$ and mechanical coupling that prevent follower cells from becoming leaders ${ }^{25,26}$. Interestingly, during wound healing, metalloproteinase expression differs between leading and trailing populations (reviewed in 34-36). Matrix metalloproteinase 1 (MMP1), 9 and 10 are expressed in keratinocytes at the leading edge ${ }^{35}$, while other MMPs are expressed by keratinocytes away from the leading edge, such as MMP3 ${ }^{36}$ and MMP $28^{37}$, or by stromal cells near the wound, like MMP8 ${ }^{38}$. In summary, in epithelial sheets, specialized front cells emerge at the leading edge and are maintained for long periods of time through local interactions among migratory cells, but matrix remodelling and traction forces are not restricted to these specialized cells. 
In invasive carcinoma (tumour of an epithelial tissue), cancer cells invade by themselves with tip cells either adopting a pseudomesenchymal phenotype or associated with non-tumoral cells such as cancer-associated fibroblasts $(\mathrm{CAFs})^{39}$. In the former case, tip cells are similar to leader cells emerging in the aforementioned epithelial monolayers. The emergence of leader cancer cells can be enhanced via environmental changes such as local increase of compression $^{40}$. In the latter case, CAFs are thought to be induced from various cell types to become invasive, capable of matrix remodelling (that is, expressing MMP2, 9 and 14) and able to determine the directionality of the metastatic group. CAFs can generate tracks in the matrix for cancer cells to use $\mathrm{e}^{41,42}$ and even directly pull cancer cells out of a tumour ${ }^{43}$. The strand formed by a leading CAF followed by carcinoma cells resembles the structure of epithelial fingers described above.

Angiogenesis is the process by which new blood vessels are formed from existing vessels. At the onset of vessel sprouting, all endothelial cells are able to respond to the chemoattractant VEGF (vascular endothelium-derived growth factor) by upregulating the expression of the Notch ligand Dll4 (Delta like-4), which results in the downregulation of VEGF receptor in adjacent cells. In this manner, the VEGF-Dll4/Notch lateral inhibition pathway generates heterogeneity in the population and singles out tip (leader) cells ${ }^{44}$. Importantly, high levels of VEGF activity also determine tip cell morphology by inducing the formation of large lamellipodia and high numbers of filopodia and defining the strength of cell-cell adhesion by controlling the polarized presentation of vascular endothelial (VE)-cadherin at the cell surface ${ }^{45}$. In the stalk (follower cell), on the other hand, active Notch signalling interacts with the Wnt/PCP pathway to define its polarity and differentiation (lumen formation). In consequence, transcriptional control through Notch lateral inhibition initially sorts out leader cells and then maintains the identity of follower cells. Dynamic identity allocation, that is concomitant with movement, can also be achieved by asymmetric cell division ${ }^{46}$. To summarize, in this system, tip cells have a highly dynamic actin cytoskeleton with a large protrusion and are mechanically coupled via cadherins and actomyosin to their direct followers ${ }^{47}$. Functionally, epithelial/ endothelial fingers or strands resemble a bike with multiple riders (Figure 1A). All riders are interconnected, they all contribute physically but the front rider sets the directionality of the course.

Border cells in Drosophila ovaries form a small cluster of about eight cells in total, organized around a core of two immobile cells named polar cells ${ }^{48}$. They migrate through the surrounding nurse cells towards the oocyte in two distinct ways. An almost linear migration (the running mode) dominates during the earliest phase towards the oocyte. Running is characterized by protrusive activity essentially restricted to the front cell and oriented towards the nurse cells facing $\mathrm{it}^{49}$. The late phase of displacement, near the oocyte, is dominated by the rotating mode of migration. During rotation, all cells display protrusive activity, protrusions are even detected in between border cells and some neighbour exchange can take place ${ }^{49}$. During the running part of the migration, the cluster has one front cell at a time. The role of leader is taken by the cell that better responds to the external gradient of molecules secreted by the oocyte, including PVF (platelet-derived/vascular endothelium-derived growth factor homologue) and epidermal growth factor (EGF) ligands ${ }^{48,50}$. The cell with the highest receptor tyrosine kinase signalling levels in turn generates higher Rac1 levels, resulting in the formation of a stronger protrusion, which allows this cell to take the leading role. As in sheets, the mechanical coupling of the cells via cadherin junction within the cluster prevents other cells from forming protrusions ${ }^{51-55}$. Impairing this physical coupling induces the formation of protrusions in all cells and loss of directional migration. This is in agreement with the observation that during the rotating phase all cells display high protrusive activity ${ }^{49}$. Furthermore, mechanical coupling is such that experimental activation of Rac1 in a cell different from the leader $^{56}$ inhibits protrusion formation elsewhere in the group and migration is redirected to a new location. In summary, in border cells, during the linear migration phase, a leader emerges in response to an environmental chemoattractant and leaderfollower roles are maintained via mechanical coupling preventing excessive protrusive activity in non-front cells. All outer, migratory cells of the group contribute motile force, but the lead cell likely contributes more than followers ${ }^{13}$. Occasionally, a follower cell takes over the lead position and this suggests that there is nothing unique in the identity of the lead cell. The reasons behind this turnover remain unknown. Although desensitization by endocytosis of the guidance receptor may explain this behaviour, cell turnover has been proposed as a mechanism to prevent desensitization in large groups of chemotactic immune cells ${ }^{57}$. Functionally, the border cell cluster can be compared to a sedan chair (Figure 1B). Several active persons carry passive travellers. All carriers are mechanically coupled to each other and to their passive load, but the front carriers set the direction of the course.

Mammary glands develop by progressive branching of an initial epithelium $^{58}$. Each branch has a terminal end bud migrating into the stroma. End buds are formed of non-protrusive front cells, called cap cells ${ }^{59}$, and ensheathing terminal end bud body cells that collectively migrate without direct physical contact with the local environment ${ }^{59}$. Branching is thought to depend on remodelling of the extracellular matrix by MMPs expressed by end bud cells and stromal cells. However, there is no in vivo evidence that mammary epithelial cells degrade their basement membranes. Furthermore, recent in vivo data indicate that MMP14 and 15 found in the terminal end bud during branching are required for non-catalytic purposes (see 60 for further discussion). Therefore, in this system, front cells are not pathfinding, they do not actively remodel the matrix in vivo and the bulk of the traction force is coming from motile end bud body cells that do not occupy the leading edge position.

Ganglia of the cranial nerves VII, IX and $\mathrm{X}$ are formed by neural crest and epibranchial placodal cells ${ }^{61}$. These placodes are epithelial cells located laterally to the neural plate at early stages of development ${ }^{62}$. Epibranchial placode precursors collectively migrate ventrally and progressively split into distinct subgroups distributed along the antero-posterior axis. Interestingly, placodal cells are motile but lack directionality on their own. They produce a chemokine CXCL12 that attracts nearby, dorsally located, neural crest cells. When a physical contact occurs, N-cadherin-dependent contact inhibition of locomotion promotes the collapse of cell 
A

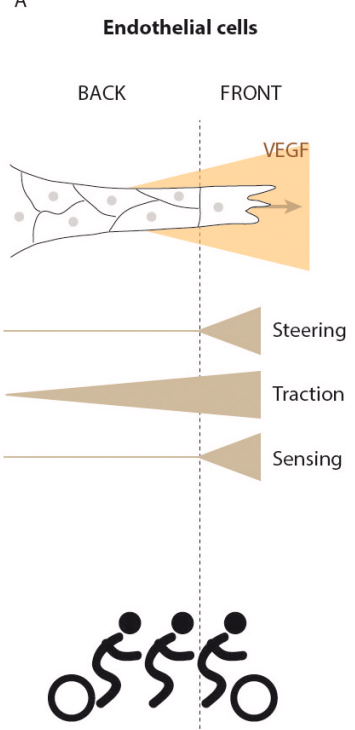

B

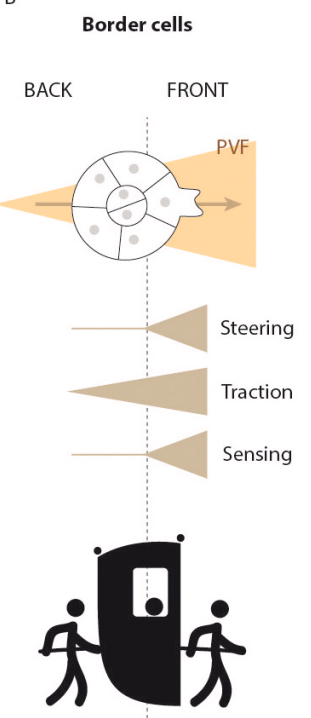

C

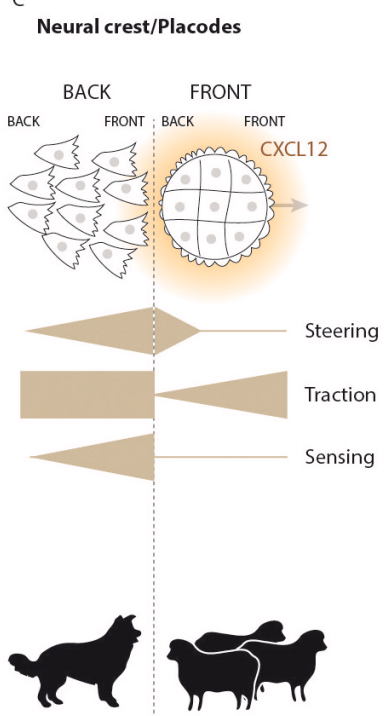

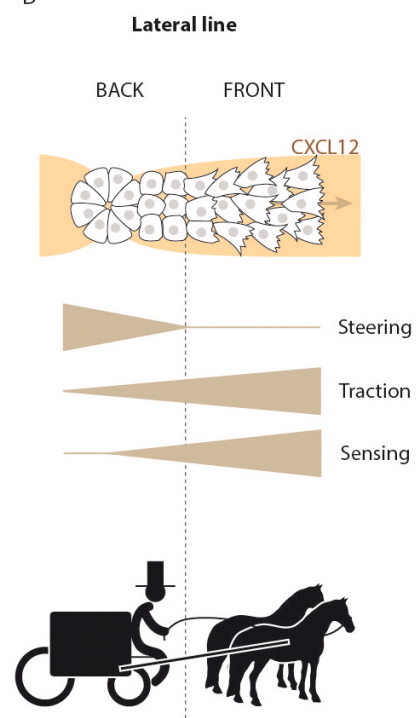

Figure 1. The many ways of steering a cell collective. (A) Endothelial cells. One tip cell responds to vascular endothelium-derived growth factor (VEGF) and adopts a pseudomesenchymal phenotype with distinctive lamellipodia. This works as a bicycle with multiple riders (tandem, triplets, quads or quints). The front cyclist (the tip cell) is responsible for sensing and steering while traction force is shared among cyclists (B) Border cells. One cell responds better to platelet-derived/vascular endothelium-derived growth factor homologue (PVF) and adopts a pseudomesenchymal phenotype with a distinctive protrusion. This works as several persons carrying a sedan chair. The front person (front cell) is responsible for sensing and steering and exerts traction force but all cells are mechanically coupled and traction is shared. (C) Placodes and neural crest cells. Epithelial placodes and mesenchymal neural crest cells have intrinsic motility (low for placodes and high for neural crest cells) but no directionality on their own. Neural crest cells sense placodes via Cxcl12. Placodes do not sense an external cue but are repelled by repeated physical contact with the neural crest. This works as a sheepdog (neural crest cells) and livestock (placodes) interaction. The sheepdog (highly motile) is attracted by the livestock (gregarious). The livestock only moves to go away from the sheepdog. When they are separated, motility is conserved but directionality is lost. (D) Lateral line primordium. Front cells are mesenchymal while back cells are epithelial. Homogenous Cxcl12 distribution is transiently and locally converted into a gradient by the back cells. Front cells sense this gradient. This works as horse-drawn carriage. The driver in the carriage (back cells) is responsible for steering while horses (front cells) follow available instructions and pull the whole structure. When the two are separated, horses remain motile but lose directionality while the carriage is immobile.

protrusion on both cell populations ${ }^{63}$. However, neural crest cells are more motile and systematically fill the gap. This difference in motility biases the direction of movement such that neural crest cells progressively repel placodes to advance ventrally. The two populations migrate in a coordinated manner with placodes at the front and neural crest cells at the back displaying a chase-and-run (attraction-repulsion) behaviour ${ }^{63}$. Contrary to the CAF-cancer cell situation, in this case neural crest cells are the cells that set the directionality to the group and the directional migration of placodal cells is not initiated by cells present at the front of the placode population. It is the transient, repeated, physical contacts between neural crest cells and placodes, occurring at the back of the placode population, that consistently inhibit the formation of lasting protrusions by back placodal cells. This mechanism establishes a front-rear polarity across the placodal group and sustains their ventral-ward directional movement. At the single level, the importance of the back (or rear) for the emergence and stabilization of polarity is well known and has been discussed elsewhere in the context of collective cell migration ${ }^{4,64}$. The heterotypic neural crest/ placode relationship works similarly to a sheepdog (neural crest) and cattle (placodes) situation (Figure 1C).
Overall, data on epithelial cells show that directional collective migration can occur in groups where (i) traction forces and matrix remodelling capabilities are shared among migratory cells even when a morphologically distinct tip cell is present (epithelial fingers, vessels sprouting, border cells), (ii) front cells do not display extensive protrusive or matrix remodelling capabilities (mammary gland), and (iii) specific events take place at the rear rather than at the front of the population (placodes).

\section{Mesenchymal models of collective cell migration}

The main models for the analysis of collective migration in mesenchymal cells are the neural crest and the lateral line primordium populations. Neural crest cells are a highly migratory population that emerges from the dorsal neuroepithelium and colonizes the entire developing embryo ${ }^{65}$.

Cephalic neural crest cells from Xenopus and fish embryos polarize according to their contact with other cells and the cellfree space through contact inhibition of locomotion (CIL), which is mediated by homophilic cadherin contacts ${ }^{66,67}$. In an unbiased environment, CIL promotes the radial dispersion of cells. This is 
simply because cells facing the cell-free interface do not experience CIL all around their cell membrane. Cells polarize accordingly, forming a protrusion towards the cell-free space and move away from the main group. In vivo, this mechanism is reinforced by confinement ${ }^{68}$ and the chemoattractant CXCL12 that positively biases the protrusion lifetime ${ }^{69}$. In vitro, cells at the front of the group at any given time present larger and more stable protrusion than the rest of the cells. Yet their actual impact on the direction of followers has not been established. Indeed, the combination of cell cooperation via adhesion ${ }^{69}$, paracrine signalling ${ }^{70}$ and confinement ${ }^{68}$ is sufficient to promote directional movement in the absence of chemotaxis ${ }^{9,68}$

Experiments in chick embryos combining transcriptomic analysis and computational modelling support the importance of cell-cell contact for neural crest migration ${ }^{71-73}$ but bring into play different roles for cells at distinct positions of the group ${ }^{74-77}$. A small number of specialized trailblazer cells at the migration front, presenting a stable and characteristic transcriptomic signature, would be the only cells that respond to a gradient of the chemoattractant VEGF. Accordingly, trailblazers direct the movement of follower cells directly in contact with them. These followers in turn contact cells further back, forming chains of directionally migrating cells. The gradient of VEGF would be sculpted by the neural crest population as a consequence of the different response to VEGF of front and back cells. While trailblazers could bind and respond to VEGF, follower cells can only bind and consume the factor, acting as a sink ${ }^{78}$. While this is an interesting proposition, the existence of a VEGF gradient remains speculative. In addition, the importance of the transcriptomic differences observed for the migratory behaviour of cephalic chick neural crest has not been functionally tested.

A different analysis using in vivo tracking of cephalic neural crest in chick and fish embryos revealed that the relative position of cells within the group is not stable during migration ${ }^{79}$. Cells intermingle every time they move the equivalent of one cell diameter (about every 50 minutes), and only $5 \%$ of the cells retain the front position throughout migration. Furthermore, the migration of the group is not altered by the total ablation of front cells. Together, these observations show that all cells in the group have the capability to imbue directionality and that cells occupy the front positions only transiently. One possibility for such quick adaptation would be via the selective presentation of CXCR4 at the cell surface. CXCR4, the main receptor of CXCL12, could localize at the cell membrane in a cell-cell adhesion-dependent manner downstream of CIL. The activity of the exocyst complex is influenced by cadherin junctions ${ }^{80}$, and cytoplasmic pools of CXCR4 are driven to the plasma membrane by this pathway in human cancer cells ${ }^{81}$. Therefore, as soon as a cell reaches the migration front and acquires a free edge, differential endocytosis would enrich the guidance receptor CXCR4 at the front of the cell. This mechanism would explain the seemingly immediate acquisition of leader traits as it does not require transcriptional or translational delays. In such a case, the characteristic trailblazer transcriptomic signature would be the consequence, and not the cause, of leading edge incorporation.
Alternatively, cells at the front of the cephalic neural crest population may not represent a subgroup of specialized cells. Leader/trailblazer identity would not exist as such. Interestingly, CXCR4 mRNA is detected in the whole population in a salt-and-pepper manner in chick $^{82,83}$, fish ${ }^{84}$, mouse ${ }^{82}$ and Xenopus $^{69}$ embryos. Thus, CXCL12-responding cells are expected to be found throughout the migrating group. In silico data, previously discussed, indicate that chemotaxing cells within a migrating group can influence the directionality of their neighbours if a functional mechanical connection exists (that is, CIL for neural crest $)^{10}$. Thus, CXCL12 signalling could very well bias migration by acting only on CXCR4-positive cells that are scattered within the population. In this case, there would be no need for a specialized group of front cells or a fancy (and speculative) contactdependent endocytosis of CXCR4. Similarly to the widespread expression of CXCR4, numerous proteolytic enzymes from the MMP and ADAM families (that is, MMP2/8/9/14/15/17 and ADAM9/10/13/19) are expressed throughout the cephalic neural crest population in chick $^{85-88}$, mouse ${ }^{89}$, fish ${ }^{90-92}$ and Xenopus ${ }^{93-98}$. This strongly suggests that proteolytic capabilities are shared among cephalic neural crest cells and might further explain why specific ablation of front cells did not impair migration.

In the trunk of fish embryos, neural crest cells migrate as a single file of loosely interacting cells. Leader cells at the front of the group are a permanent population and the only cells capable of defining the directionality of the group-traits that define them as leaders. Moreover, leader and follower identities are established before initiation of migration and are not exchangeable during migration $^{79}$. The molecular pathways controlling identity specification and maintenance of trunk fish neural crest leader cells remain to be unveiled, but it is tempting to make analogies with epithelial sheets and sprouting angiogenesis where the Notch pathway plays a pivotal role.

The posterior lateral line primordium is a 150-micrometre-long heterogeneous migratory population composed in its two front thirds of mesenchymal cells while its rear third is epithelial. This structure migrates along the antero-posterior axis during late phases of fish and amphibian development to deposit mechanosensitive organs, the neuromasts ${ }^{99}$. The front mesenchymal cells are motile and display polarized and highly protrusive activity at the front of each cell. The rear cells are deposited as epithelial rosettes and are barely motile. The front and rear subpopulations are generated via Wnt/FGF-dependent communication between cells at the onset of migration ${ }^{99}$. Directionality of migration in this system is set by a gradient of the chemokine CXCL12 $2^{100}$. It has been shown that CXCL12 is homogeneously expressed along the antero-posterior axis and that the formation of a gradient results from different expression of CXCL12 receptors in front and rear populations. CXCR4 is found in all cells, whereas CXCR7 expression is restricted to epithelial rear cells ${ }^{100-103}$. CXCR4 is responsible for the chemotactic response to CXCL12, a capacity of all cells in the population ${ }^{101}$. CXCR7, on the other hand, acts as a decoy receptor that internalizes CXCL12 at the rear of the group $^{104}$. In this way, the differential localization and activity of these receptors are responsible for a self-generated local gradient 
of CXCL12 that spans the whole migratory group and creates the directional bias ${ }^{101,102}$. Removing rear cells by laser ablation ${ }^{105}$, or inhibiting CXCR7 expression $^{103}$, is sufficient to block directional migration even if protrusive activity and CXCR4 expression are not affected in front cells. Interestingly, CXCR7 expression is restricted to rear cells in a CXCR4-dependent manner, such that CXCR4 knockdown leads to widespread expression of CXCR7 through the primordium, lack of gradient formation and misguided migration ${ }^{103}$. Similar to the migration of cranial placodes, here it is a specific event (local epithelialization and restricted CXCR7 expression) occurring at the back of the migrating group that is responsible for steering the whole population in the right direction. The lateral line primordium functions as a horse-drawn carriage (Figure 1D) in which a non-mobile rear end sets the course of an otherwise non-directional mobile group.

\section{Conclusions}

The current nomenclature of leader and follower cells ties the position of a cell to its function. Moreover, it implies that front cells represent a particular subgroup of cells that guide the population by exploring the local environment, finding the path, remodelling the matrix and exerting significant traction force. In the meantime, followers are deemed passive cells mostly defined by their inability to generate their own migratory path.

However, the discussed experimental data and in silico simulations show that (i) the proposed characteristics of leader cells (pathfinding, traction force, matrix remodelling) are not systematically associated with front cells, (ii) directional collective migration can emerge from homogenous cell populations subjected to external information (gradients, confinement), and (iii) when specialized cells are present these are not necessarily organized as a specific subgroup or positioned at the leading edge. In this context, we think that the leader cell terminology should be simplified and restricted to a specific subset of cases. Leaders are defined as front cells that imbue directionality to the entire group. They may do so in various non-exclusive ways such as displaying an intense protrusive activity, specifically expressing a guidance receptor. The particular mechanism may differ depending on the population studied and the local environment in which migration takes place.
In order to have a term that could apply to all situations, we propose to name the cells that set the overall directionality of a collectively migrating group: steering cells. To steer means "to guide in a particular direction or manner"; we think it is an appropriately ample term that does not imply how the guidance is achieved and that does not associate it with a particular location. That is a general term based solely on a cell's function that does not overlap and therefore can be used in combination with purely topological terms such as front and rear (or back). Steering cells may be at the front or not. They may be motile or not. Therefore, when studying what controls directionality, one should (i) experimentally test whether the population is homogenous (Are all cells required for directionality? Are some subgroups required and others dispensable?), (ii) explore the mechanisms at play (external gradient, paracrine communication, physical contact, and confinement) and (iii) define which cells respond to what signals.

This concept of steering cells does not preclude the possibility of complex systems where some cells scattered throughout the population might chemotax while a subset of front cells could exhibit proteolytic activities, for instance. There may be several categories of steering cells within a collective.

\section{Competing interests}

The authors declare that they have no competing interests.

\section{Grant information}

Work in the ET lab is supported by the Centre National de la Recherche Scientifique (CNRS) and grants from the Fondation pour la Recherche Médicale (FRM AJE201224), the Midi-Pyrénées regional council (13053025) and Fondation Toulouse Cancer Santé (Math/Bio Interface grant). Work in the CL lab is supported by the Medical Research Council and the Wellcome Trust.

The funders had no role in study design, data collection and analysis, decision to publish, or preparation of the manuscript.

\section{Acknowledgements}

We are grateful to Pascal Silberzan, Nicolas David and Bertrand Bénazéraf for critical comments on the manuscript.
1. Friedl P, Mayor R: Tuning Collective Cell Migration by Cell-Cell Junction Regulation. Cold Spring Harb Perspect Biol. 2017; 9(4): pii: a029199. PubMed Abstract | Publisher Full Text

2. Hakim V, Silberzan P: Collective cell migration: a physics perspective. Rep Prog Phys. 2017; 80(7): 076601

PubMed Abstract | Publisher Full Text

3. Theveneau E, Mayor R: Collective cell migration of epithelial and mesenchymal cells. Cell Mol Life Sci. 2013; 70(19): 3481-92. PubMed Abstract | Publisher Full Text

4. Mayor R, Etienne-Manneville $\mathrm{S}$ : The front and rear of collective cell migration. Nat Rev Mol Cell Biol. 2016; 17(2): 97-109. PubMed Abstract | Publisher Full Text
5. Haeger A, Wolf K, Zegers MM, et al:: Collective cell migration: guidance principles and hierarchies. Trends Cell Biol. 2015; 25(9): 556-66. PubMed Abstract | Publisher Full Text

6. Khalil AA, Friedl P: Determinants of leader cells in collective cell migration. Integr Biol (Camb). 2010; 2(11-12): 568-74.

PubMed Abstract | Publisher Full Text

7. Haeger A, Krause M, Wolf K, et al:: Cell jamming: collective invasion of mesenchymal tumor cells imposed by tissue confinement. Biochim Biophys Acta. 2014; 1840(8): 2386-95.

PubMed Abstract | Publisher Full Text

8. Schumacher LJ, Kulesa PM, McLennan R, et al.: Multidisciplinary approaches to understanding collective cell migration in developmental biology. Open Biol. 
2016; 6(6): pii: 160056.

PubMed Abstract | Publisher Full Text | Free Full Text

9. F Szabó A, Mayor R: Modelling collective cell migration of neural crest. Curr Opin Cell Biol. 2016; 42: 22-8.

PubMed Abstract | Publisher Full Text | Free Full Text | F1000 Recommendation

10. F Kabla AJ: Collective cell migration: leadership, invasion and segregation. $J$ R Soc Interface. 2012; 9(77): 3268-78.

PubMed Abstract | Publisher Full Text | Free Full Text | F1000 Recommendation

11. F Ferguson EA, Matthiopoulos J, Insall RH, et al:: Inference of the drivers of collective movement in two cell types: Dictyostelium and melanoma. $J R$ Soc Interface. 2016; 13(123): pii: 20160695.

PubMed Abstract | Publisher Full Text | Free Full Text | F1000 Recommendation

12. Méhes $\mathrm{E}$, Vicsek T: Collective motion of cells: from experiments to models. Integr Biol (Camb). 2014; 6(9): 831-54.

PubMed Abstract | Publisher Full Tex

13. F Cai D, Dai W, Prasad M, et al.: Modeling and analysis of collective cell migration in an in vivo three-dimensional environment. Proc Natl Acad Sci U S A. 2016; 113(15): E2134-41.

PubMed Abstract | Publisher Full Text | Free Full Text | F1000 Recommendation

14. Bi D, Yang $X$, Marchetti MC, et al.: Motility-driven glass and jamming transitions in biological tissues. Phys Rev X. 2016; 6(2): pii: 021011.

PubMed Abstract | Publisher Full Text | Free Full Text

15. Ariel G, Ayali A: Locust Collective Motion and Its Modeling. PLoS Comput Biol. 2015; 11(12): e1004522.

PubMed Abstract | Publisher Full Text | Free Full Text

16. Ranft J, Basan M, Elgeti J, et al.: Fluidization of tissues by cell division and apoptosis. Proc Natl Acad Sci U S A. 2010; 107(49): 20863-8.

PubMed Abstract | Publisher Full Text | Free Full Text

17. Prost J, Jülicher F, Joanny JF: Active gel physics. Nat Phys. 2015; 11: 111-7. Publisher Full Text

18. Lee $\mathrm{P}$, Wolgemuth $\mathrm{CW}$ : Crawling cells can close wounds without purse strings or signaling. PLoS Comput Biol. 2011; 7(3): e1002007. PubMed Abstract | Publisher Full Text | Free Full Text

19. Poujade M, Grasland-Mongrain E, Hertzog A, et al.: Collective migration of an epithelial monolayer in response to a model wound. Proc Natl Acad Sci U S A. 2007; 104(41): 15988-93.

PubMed Abstract | Publisher Full Text | Free Full Text

20. Trepat $\mathrm{X}$, Fredberg JJ: Plithotaxis and emergent dynamics in collective cellula migration. Trends Cell Biol. 2011; 21(11): 638-46.

PubMed Abstract | Publisher Full Text | Free Full Text

21. Geudens I, Gerhardt H: Coordinating cell behaviour during blood vessel formation. Development. 2011; 138(21): 4569-83.

PubMed Abstract | Publisher Full Text

22. Ochoa-Espinosa A, Affolter M: Branching morphogenesis: from cells to organs and back. Cold Spring Harb Perspect Biol. 2012; 4(10): pii: a008243. PubMed Abstract | Publisher Full Text | Free Full Text

23. Kong $D$, Wolf $F$, Großhans J: Forces directing germ-band extension in Drosophila embryos. Mech Dev. 2017; 144(Pt A): 11-22. PubMed Abstract | Publisher Full Text

24. F Prasad M, Wang X, He L, et al:: Border Cell Migration: A Model System for Live Imaging and Genetic Analysis of Collective Cell Movement. Methods $\mathrm{MO}$ Biol. 2015; 1328: 89-97.

PubMed Abstract | Publisher Full Text | Free Full Text | F1000 Recommendation

25. F Riahi R, Sun J, Wang S, et al:: Notch1-DII4 signalling and mechanical force regulate leader cell formation during collective cell migration. Nat Commun. 2015; 6: 6556

PubMed Abstract | Publisher Full Text | Free Full Text | F1000 Recommendation

26. F Kollimada SA, Kulkarni AH, Ravan A, et al.: Advancing Edge Speeds of Epithelial Monolayers Depend on Their Initial Confining Geometry. PLOS One. 2016; 11(4): e0153471.

PubMed Abstract | Publisher Full Text | Free Full Text | F1000 Recommendation

27. F Plutoni C, Bazellieres E, Le Borgne-Rochet M, et al.: P-cadherin promotes collective cell migration via a Cdc42-mediated increase in mechanical forces. $J$ Cell Biol. 2016; 212(2): 199-217.

PubMed Abstract | Publisher Full Text | Free Full Text | F1000 Recommendation

28. F Sunyer R, Conte V, Escribano J, et al.: Collective cell durotaxis emerges from long-range intercellular force transmission. Science. 2016; 353(6304): 1157-61.

PubMed Abstract | Publisher Full Text | F1000 Recommendation

29. F Brugués $A$, Anon $E$, Conte $V$, et al:: Forces driving epithelial wound healing Nat Phys. 2014; 10(9): 683-90.

PubMed Abstract | Publisher Full Text | Free Full Text | F1000 Recommendation

30. F Reffay M, Parrini MC, Cochet-Escartin O, et al:: Interplay of RhoA and mechanical forces in collective cell migration driven by leader cells. Nat Cell Biol. 2014; 16(3): 217-23.

PubMed Abstract | Publisher Full Text | F1000 Recommendation

31. F Yamaguchi N, Mizutani T, Kawabata K, et al.: Leader cells regulate collective cell migration via Rac activation in the downstream signaling of integrin $\beta 1$ and PI3K. Sci Rep. 2015; 5: 7656.

PubMed Abstract | Publisher Full Text | Free Full Text | F1000 Recommendation

32. F Yokoyama S, Matsui TS, Deguchi S: New wrinkling substrate assay reveals traction force fields of leader and follower cells undergoing collective migration. Biochem Biophys Res Commun. 2017; 482(4): 975-9.

PubMed Abstract | Publisher Full Text | F1000 Recommendation

33. F Serra-Picamal X, Conte V, Sunyer R, et al.: Mapping forces and kinematics during collective cell migration. Methods Cell Biol. 2015; 125: 309-30. PubMed Abstract | Publisher Full Text | F1000 Recommendation

34. Caley MP, Martins VL, O'Toole EA: Metalloproteinases and Wound Healing. Adv Wound Care (New Rochelle). 2015; 4(4): 225-34.

PubMed Abstract | Publisher Full Text | Free Full Text

35. Rohani MG, Parks WC: Matrix remodeling by MMPs during wound repair. Matrix Biol. 2015; 44-46: 113-21.

PubMed Abstract | Publisher Full Text

36. Saarialho-Kere UK, Pentland AP, Birkedal-Hansen H, et al:: Distinct population of basal keratinocytes express stromelysin-1 and stromelysin-2 in chronic wounds. J Clin Invest. 1994; 94(1): 79-88.

PubMed Abstract | Publisher Full Text | Free Full Text

37. Saarialho-Kere U, Kerkelä E, Jahkola T, et al.: Epilysin (MMP-28) expression is associated with cell proliferation during epithelial repair. $J$ Invest Dermatol. 2002; 119(1): 14-21.

PubMed Abstract | Publisher Full Tex

38. Danielsen PL, Holst AV, Maltesen HR, et al:: Matrix metalloproteinase-8 overexpression prevents proper tissue repair. Surgery. 2011; 150(5): 897-906. PubMed Abstract | Publisher Full Text

39. Gascard P, TIsty TD: Carcinoma-associated fibroblasts: orchestrating the composition of malignancy. Genes Dev. 2016; 30(9): 1002-19. PubMed Abstract | Publisher Full Text | Free Full Text

40. Tse JM, Cheng G, Tyrrell JA, et al:: Mechanical compression drives cancer cells toward invasive phenotype. Proc Natl Acad Sci U S A. 2012; 109(3): 911-6. PubMed Abstract | Publisher Full Text | Free Full Text

41. F Gaggioli C, Hooper S, Hidalgo-Carcedo C, et al:: Fibroblast-led collective nvasion of carcinoma cells with differing roles for RhoGTPases in leading and following cells. Nat Cell Biol. 2007; 9(12): 1392-400.

PubMed Abstract | Publisher Full Text | F1000 Recommendation

42. Attieh Y, Vignjevic DM: The hallmarks of CAFs in cancer invasion. Eur J Cell Biol 2016; 95(11): 493-502.

PubMed Abstract | Publisher Full Text

43. F Labernadie A, Kato T, Brugués A, et al:: A mechanically active heterotypic $\mathrm{E}$-cadherin/ $\mathrm{N}$-cadherin adhesion enables fibroblasts to drive cancer cell invasion. Nat Cell Biol. 2017; 19(3): 224-37. PubMed Abstract | Publisher Full Text | F1000 Recommendation

44. F Ubezio B, Blanco RA, Geudens I, et al:: Synchronization of endothelial DII4Notch dynamics switch blood vessels from branching to expansion. eLife. 2016; 5: pii: e12167.

PubMed Abstract | Publisher Full Text | Free Full Text | F1000 Recommendation

45. F Bentley K, Franco CA, Philippides A, et al:: The role of differential VEcadherin dynamics in cell rearrangement during angiogenesis. Nat Cell Biol. 2014; 16(4): 309-21.

PubMed Abstract | Publisher Full Text | F1000 Recommendation

46. F Costa G, Harrington $\mathrm{KI}$, Lovegrove $\mathrm{HE}$, et al:: Asymmetric division coordinates collective cell migration in angiogenesis. Nat Cell Biol. 2016; 18(12): 1292-301. PubMed Abstract | Publisher Full Text | Free Full Text | F1000 Recommendation

47. F Yang Y, Jamilpour N, Yao B, et al.: Probing Leader Cells in Endothelial Collective Migration by Plasma Lithography Geometric Confinement. Sci Rep. 2016; 6: 22707.

PubMed Abstract | Publisher Full Text | Free Full Text | F1000 Recommendation

48. F Bianco A, Poukkula M, Cliffe A, et al:: Two distinct modes of guidance signalling during collective migration of border cells. Nature. 2007; 448(7151): 362-5.

PubMed Abstract | Publisher Full Text | F1000 Recommendation

49. F Cliffe A, Doupé DP, Sung H, et al:: Quantitative 3D analysis of complex single border cell behaviors in coordinated collective cell migration. Nat Commun. 2017; 8: 14905

PubMed Abstract | Publisher Full Text | Free Full Text | F1000 Recommendation

50. Inaki M, Vishnu S, Cliffe $\mathrm{A}$, et al.: Effective guidance of collective migration based on differences in cell states. Proc Natl Acad Sci U S A. 2012; 109(6): $2027-32$

PubMed Abstract | Publisher Full Text | Free Full Tex

51. F Combedazou A, Choesmel-Cadamuro V, Gay G, et al:: Myosin II governs collective cell migration behaviour downstream of guidance receptor signalling. J Cell Sci. 2017; 130(1): 97-103.

PubMed Abstract | Publisher Full Text | F1000 Recommendation

52. F Cai D, Chen SC, Prasad M, et al:: Mechanical feedback through E-cadherin promotes direction sensing during collective cell migration. Cell. 2014; 157(5): $1146-59$

PubMed Abstract | Publisher Full Text | Free Full Text | F1000 Recommendation 
53. Montell DJ, Yoon WH, Starz-Gaiano M: Group choreography: mechanisms orchestrating the collective movement of border cells. Nat Rev Mol Cell Biol. 2012; 13(10): 631-45.

PubMed Abstract | Publisher Full Text | Free Full Text

54. F Colombié N, Choesmel-Cadamuro V, Series J, et al:: Non-autonomous role of Cdc42 in cell-cell communication during collective migration. Dev Biol. 2017; 423(1): $12-8$.

PubMed Abstract | Publisher Full Text | F1000 Recommendation

55. Fernández-Espartero $\mathrm{CH}$, Ramel D, Farago M, et al.: GTP exchange factor Vav regulates guided cell migration by coupling guidance receptor signalling to local Rac activation. J Cell Sci. 2013; 126(Pt 10): 2285-93. PubMed Abstract | Publisher Full Text

56. F Wang $\mathrm{X}, \mathrm{He} \mathrm{L}, \mathrm{Wu} Y \mathrm{Yl}$, et al:: Light-mediated activation reveals a key role for Rac in collective guidance of cell movement in vivo. Nat Cell Biol. 2010; 12(6): $591-7$.

PubMed Abstract | Publisher Full Text | Free Full Text | F1000 Recommendation

57. F Malet-Engra G, Yu W, Oldani A, et al:: Collective cell motility promotes chemotactic prowess and resistance to chemorepulsion. Curr Biol. 2015; 25(2): 242-50.

PubMed Abstract | Publisher Full Text | F1000 Recommendation

58. Inman JL, Robertson C, Mott JD, et al:: Mammary gland development: cell fate specification, stem cells and the microenvironment. Development. 2015; 142(6): 1028-42.

PubMed Abstract | Publisher Full Text

59. Spurlin JW 3rd, Nelson CM: Building branched tissue structures: from single cell guidance to coordinated construction. Philos Trans $R$ Soc Lond B Biol Sci. 2017; 372(1720): pii: 20150527.

PubMed Abstract | Publisher Full Text | Free Full Text

60. F Feinberg TY, Rowe RG, Saunders TL, et al.: Functional roles of MMP14 and MMP15 in early postnatal mammary gland development. Development. 2016; 143(21): 3956-68.

PubMed Abstract | Publisher Full Text | Free Full Text | F1000 Recommendation

61. Theveneau E, Mayor R: Collective cell migration of the cephalic neural crest: the art of integrating information. Genesis. 2011; 49(4): 164-76. PubMed Abstract | Publisher Full Text

62. Schlosser G: Vertebrate cranial placodes as evolutionary innovations--the ancestor's tale. Curr Top Dev Biol. 2015; 111: 235-300.

PubMed Abstract | Publisher Full Text

63. F Theveneau E, Steventon B, Scarpa E, et al:: Chase-and-run between adjacent cell populations promotes directional collective migration. Nat Cell Biol. 2013; 15(7): 763-72

PubMed Abstract | Publisher Full Text | Free Full Text | F1000 Recommendation

64. Petrie RJ, Doyle AD, Yamada KM: Random versus directionally persistent cell migration. Nat Rev Mol Cell Biol. 2009; 10(8): 538-49.

PubMed Abstract | Publisher Full Text | Free Full Text

65. F Theveneau E, Mayor R: Neural crest delamination and migration: from epithelium-to-mesenchyme transition to collective cell migration. Dev Biol. 2012; 366(1): 34-54.

PubMed Abstract | Publisher Full Text | F1000 Recommendation

66. Stramer B, Mayor R: Mechanisms and in vivo functions of contact inhibition of locomotion. Nat Rev Mol Cell Biol. 2016.

PubMed Abstract | Publisher Full Text

67. F Carmona-Fontaine C, Matthews HK, Kuriyama S, et al.: Contact inhibition of locomotion in vivo controls neural crest directional migration. Nature. 2008; 456(7224): 957-61.

PubMed Abstract | Publisher Full Text | Free Full Text | F1000 Recommendation

68. F Szabó A, Melchionda M, Nastasi G, et al:: In vivo confinement promotes collective migration of neural crest cells. J Cell Biol. 2016; 213(5): 543-55. PubMed Abstract | Publisher Full Text | Free Full Text | F1000 Recommendation

69. F Theveneau E, Marchant L, Kuriyama S, et al:: Collective chemotaxis requires contact-dependent cell polarity. Dev Cell. 2010; 19(1): 39-53.

PubMed Abstract | Publisher Full Text | Free Full Text | F1000 Recommendation

70. F Carmona-Fontaine C, Theveneau E, Tzekou A, et al:: Complement fragment C3a controls mutual cell attraction during collective cell migration. Dev Cell. 2011; 21(6): 1026-37.

PubMed Abstract | Publisher Full Text | Free Full Text | F1000 Recommendation

71. Kulesa PM, Fraser SE: Neural crest cell dynamics revealed by time-lapse video microscopy of whole embryo chick explant cultures. Dev Biol. 1998; 204(2): 327-44.

PubMed Abstract | Publisher Full Text

72. Kulesa PM, Fraser SE: In ovo time-lapse analysis of chick hindbrain neural crest cell migration shows cell interactions during migration to the branchial arches. Development. 2000; 127(6): 1161-72. PubMed Abstract

73. F Teddy JM, Kulesa PM: In vivo evidence for short- and long-range cell communication in cranial neural crest cells. Development. 2004; 131(24): 6141-51.

PubMed Abstract | Publisher Full Text | F1000 Recommendation
74. F McLennan R, Schumacher LJ, Morrison JA, et al:: Neural crest migration is driven by a few trailblazer cells with a unique molecular signature narrowly confined to the invasive front. Development. 2015; 142(11): 2014-25. PubMed Abstract | Publisher Full Text | F1000 Recommendation

75. F McLennan R, Schumacher LJ, Morrison JA, et al:: VEGF signals induce trailblazer cell identity that drives neural crest migration. Dev Biol. 2015; 407(1): 12-25.

PubMed Abstract | Publisher Full Text | F1000 Recommendation

76. Wynn ML, Rupp P, Trainor PA, et al.: Follow-the-leader cell migration requires biased cell-cell contact and local microenvironmental signals. Phys Biol. 2013; 10(3): 35003

PubMed Abstract | Publisher Full Text | Free Full Text

77. Wynn ML, Kulesa PM, Schnell S: Computational modelling of cell chain migration reveals mechanisms that sustain follow-the-leader behaviour. $J R$ Soc Interface. 2012; 9(72): 1576-88.

PubMed Abstract | Publisher Full Text | Free Full Text

78. F McLennan R, Dyson L, Prather KW, et al:: Multiscale mechanisms of cell migration during development: theory and experiment. Development. 2012; 139(16): 2935-44.

PubMed Abstract | Publisher Full Text | Free Full Text | F1000 Recommendation

79. Richardson J, Gauert A, Briones Montecinos L, et al:: Leader Cells Define Directionality of Trunk, but Not Cranial, Neural Crest Cell Migration. Cell Rep. 2016; 15(6): 2076-88.

PubMed Abstract | Publisher Full Text | Free Full Text

80. F Martin-Urdiroz M, Deeks MJ, Horton CG, et al:: The Exocyst Complex in Health and Disease. Front Cell Dev Biol. 2016; 4: 24

PubMed Abstract | Publisher Full Text | Free Full Text | F1000 Recommendation

81. Cepeda EB, Dediulia T, Fernando J, et al.: Mechanisms regulating cell membrane localization of the chemokine receptor CXCR4 in human hepatocarcinoma cells. Biochim Biophys Acta. 2015; 1853(5): 1205-18. PubMed Abstract | Publisher Full Text

82. Escot $\mathrm{S}$, Blavet $\mathrm{C}$, Faure $\mathrm{E}$, et al.: Disruption of CXCR4 signaling in pharyngea neural crest cells causes DiGeorge syndrome-like malformations.

Development. 2016; 143(4): 582-8.

PubMed Abstract | Publisher Full Tex

83. F Escot S, Blavet C, Härtle S, et al:: Misregulation of SDF1-CXCR4 signaling impairs early cardiac neural crest cell migration leading to conotruncal defects. Circ Res. 2013; 113(5): 505-16.

PublMed Abstract | Publisher Full Text | F1000 Recommendation

84. Olesnicky Killian EC, Birkholz DA, Artinger KB: A role for chemokine signaling in neural crest cell migration and craniofacial development. Dev Biol. 2009; 333(1): $161-72$.

PubMed Abstract | Publisher Full Text | Free Full Text

85. Patterson RA, Cavanaugh AM, Cantemir V, et al:: MT2-MMP expression during early avian morphogenesis. Anat Rec (Hoboken). 2013; 296(1): 64-70. PubMed Abstract | Publisher Full Text | Free Full Text

86. Cantemir V, Cai DH, Reedy MV, et al.: Tissue inhibitor of metalloproteinase-2 (TIMP-2) expression during cardiac neural crest cell migration and its role in proMMP-2 activation. Dev Dyn. 2004; 231(4): 709-19.

PubMed Abstract | Publisher Full Text

87. Duong TD, Erickson CA: MMP-2 plays an essential role in producing epithelialmesenchymal transformations in the avian embryo. Dev Dyn. 2004; 229(1): 42-53.

PubMed Abstract | Publisher Full Tex

88. Cai DH, Vollberg TM Sr, Hahn-Dantona E, et al:: MMP-2 expression during early avian cardiac and neural crest morphogenesis. Anat Rec. 2000; 259(2): 168-79. PubMed Abstract | Publisher Full Text

89. Giambernardi TA, Sakaguchi AY, Gluhak J, et al: Neutrophil collagenase (MMP-8) is expressed during early development in neural crest cells as well as in adult melanoma cells. Matrix Biol. 2001; 20(8): 577-87. PubMed Abstract | Publisher Full Text

90. Leigh NR, Schupp MO, Li K et al: Mmp17b is essential for proper neural crest cell migration in vivo. PLOS One. 2013; 8(10): e76484. PubMed Abstract | Publisher Full Text | Free Full Text

91. Quick RE, Dunlap JA, Jessen JR: Expression analysis of zebrafish membrane type-2 matrix metalloproteinases during embryonic development. Gene Exp Patterns. 2012; 12(7-8): 254-60.

PubMed Abstract | Publisher Full Text

92. Williams BB, Cantrell VA, Mundell NA, et al.: VANGL2 regulates membrane trafficking of MMP14 to control cell polarity and migration. J Cell Sci. 2012; 125(Pt 9): 2141-7.

PubMed Abstract | Publisher Full Text | Free Full Text

93. Alfandari D, Wolfsberg TG, White JM, et al:: ADAM 13: a novel ADAM expressed in somitic mesoderm and neural crest cells during Xenopus laevis development. Dev Biol. 1997; 182(2): 314-30.

PubMed Abstract | Publisher Full Text

94. Cai H, Krätzschmar J, Alfandari D, et al:: Neural crest-specific and general expression of distinct metalloprotease-disintegrins in early Xenopus laevis development. Dev Biol. 1998; 204(2): 508-24.

PubMed Abstract | Publisher Full Text 
95. F Alfandari D, Cousin H, Gaultier A, et al:: Xenopus ADAM 13 is a metalloprotease required for cranial neural crest-cell migration. Curr Biol. 2001; 11(12): 918-30. PubMed Abstract | Publisher Full Text | F1000 Recommendation

96. Neuner R, Cousin H, McCusker C, et al:: Xenopus ADAM19 is involved in neural, neural crest and muscle development. Mech Dev. 2009; 126(3-4): 240-55. PubMed Abstract | Publisher Full Text | Free Full Text

97. Tomlinson ML, Guan P, Morris RJ, et al:: A chemical genomic approach identifies matrix metalloproteinases as playing an essential and specific role in Xenopus melanophore migration. Chem Biol. 2009; 16(1): 93-104. PubMed Abstract | Publisher Full Text

98. Harrison M, Abu-Elmagd M, Grocott T, et al:: Matrix metalloproteinase genes in Xenopus development. Dev Dyn. 2004; 231(1): 214-20. PubMed Abstract | Publisher Full Text

99. F Dalle Nogare D, Chitnis AB: A framework for understanding morphogenesis and migration of the zebrafish posterior Lateral Line primordium. Mech Dev. 2017; pii: S0925-4773(17)30077-1. PubMed Abstract | Publisher Full Text | F1000 Recommendation

100. F David NB, Sapède D, Saint-Etienne L, et al:: Molecular basis of cell migration in the fish lateral line: role of the chemokine receptor CXCR4 and of its ligand,
SDF1. Proc Natl Acad Sci U S A. 2002; 99(25): 16297-302.

PubMled Abstract | Publisher Full Text | Free Full Text | F1000 Recommendation

101. F Donà E, Barry JD, Valentin G, et al.: Directional tissue migration through a self-generated chemokine gradient. Nature. 2013; 503(7475): 285-9. PubMed Abstract | Publisher Full Text | F1000 Recommendation

102. Venkiteswaran G, Lewellis SW, Wang J, et al:: Generation and dynamics of an endogenous, self-generated signaling gradient across a migrating tissue. Cell. 2013; 155(3): 674-87.

PubMed Abstract | Publisher Full Text | Free Full Text

103. Dambly-Chaudière $C$, Cubedo $N$, Ghysen $A$ : Control of cell migration in the development of the posterior lateral line: antagonistic interactions between the chemokine receptors CXCR4 and CXCR7/RDC1. BMC Dev Biol. 2007; 7: 23. PubMed Abstract | Publisher Full Text | Free Full Text

104. Mahabaleshwar H, Boldajipour B, Raz E: Killing the messenger: The role of CXCR7 in regulating primordial germ cell migration. Cell Adh Migr. 2008; 2(2): 69-70. PubMed Abstract | Publisher Full Text | Free Full Text

105. F Dalle Nogare D, Somers $\mathrm{K}$, Rao S, et al:: Leading and trailing cells cooperate in collective migration of the zebrafish posterior lateral line primordium. Development. 2014; 141(16): 3188-96.

PubMed Abstract | Publisher Full Text | Free Full Text | F1000 Recommendation 


\section{Open Peer Review}

\section{Current Peer Review Status:}

\section{Editorial Note on the Review Process}

Faculty Reviews are review articles written by the prestigious Members of Faculty Opinions. The articles are commissioned and peer reviewed before publication to ensure that the final, published version is comprehensive and accessible. The reviewers who approved the final version are listed with their names and affiliations.

\section{The reviewers who approved this article are:}

\section{Version 1}

1. Denise Montell

Molecular, Cellular, and Developmental Biology Department, University of California, Santa Barbara, Santa Barbara, USA

Competing Interests: No competing interests were disclosed.

\section{Benoit Ladoux}

Institut Jacques Monod,UMR 7592 CNRS, Universite Paris Diderot, Paris, France

Competing Interests: No competing interests were disclosed.

The benefits of publishing with F1000Research:

- Your article is published within days, with no editorial bias

- You can publish traditional articles, null/negative results, case reports, data notes and more

- The peer review process is transparent and collaborative

- Your article is indexed in PubMed after passing peer review

- Dedicated customer support at every stage

For pre-submission enquiries, contact research@f1000.com 